\title{
Female and Double Standards: A Study of Margaret Atwood's the Penelopaid
}

\author{
Jalal Hatim Rasheed
}

\author{
Al Iraqia University, College of arts, Iraq \\ Received: 18 Jul 2021; Received in revised form: 15 Aug 2021; Accepted: 22 Aug 2021 \\ (C2021 The Author(s). Published by TheShillonga. This is an open access article under the CC BY license \\ (https://creativecommons.org/licenses/by/4.0/)
}

\begin{abstract}
This paper discusses women and society's double standards against them and how Margret Atwood criticizes men through her characters. Atwood's "The Penelopiad" cross-examines the venerated wife Penelope and the maids to depict the subject of male violence and other misconducts against women. Uplifting the maids whom Odysseus kills, Atwood queries sisterhood's confines and the need for transparency, voice, respect, and justice for the overlooked female victims' powerful males have terminated. Atwood's novel signals a change in feministic philosophy from collective action to individual narratives. The Penelopiad re-appropriates the prevailing cultural myths to expose a detailed and nuanced view of a woman's meaning.
\end{abstract}

Keywords—The Penelopiad, women, double standards, traditional narratives and loyalty.

\section{INTRODUCTION}

Women and societal double standards against them is a topic that has brought about endless discussions and writings in contemporary society. In The Penelopiad (2005), Atwood transforms her heroine (Penelope) from an admirable female personality into a difficult male helper to remark on the elapsed female fatalities who haunt men. Generally, women are connected to men through friendship, romantic, or as family members. Since time immemorial, women serve as wives to help upkeep their men's reputations and perform other domestic duties. However, the price for these wives does not often equate to their responsibilities. Atwood uses multiple characters to show how double standards of society disadvantage women. This paper discusses society's double standards against women and how Atwood criticizes men through the characters of the novel "The Penelopiad". The paper discusses primary double standards of power relations, sexual double standards, double oppression, double loyalty, double oppression, double roles, and double standards of justice.

\section{Power relations}

According to Atwood, a man likes a clever woman as long as she is not a threat to his power.
${ }^{1}$ Penelope describes her marriage with Odysseus pointing to the principle of power relations, which has double standards. Penelope describes her marriage as a vulnerable situation. She says that she was given to Odysseus, similarly as a food package. Unwillingly, Odysseus acquired Penelope like perishable food. Penelope immediately became the queen of Ithaca.

She was to keep her man happy. Penelope was smart, and everyone said that to an extent, she got discouraged and bored. Therefore, Odysseus and other people valued the intelligence and skills of Penelope. However, Penelope had to remain in her confined roles as a woman. Penelope was only expected to come second after Odysseus. A further illustration of double power is shown when Odysseus mostly talked to Penelope after having sex. ${ }^{2}$ Thus, this indicates that Penelope was unwilling to participate in lovemaking. Penelope's body was to serve her husband without regarding her desires.

Penelope could only use her intelligence and skills when Odysseus departed for the Trojan War. Penelope kept an inventory of the possession of Ithaca and

\footnotetext{
${ }^{1}$ Atwood, Margaret. The Penelopiad. New York: Canongate Books Ltd. 2005. 28-19

${ }^{2}$ ibid
} 
bargained smartly. ${ }^{3}$ Penelope's smart bargaining enabled Ithaca to increase the wealth of the state. Moreover, she used her capacities in pleasing her man after he returned. The inventory tasks Penelope did were regarded as "man's business". Penelope's displeasure indicates that she was affected by the power distance emanating from men's duties even though she still did the same tasks. Penelope must seek approval from her husband before conducting any responsibilities. Seeking permission is an act of power distance. The one seeking approval is always inferior to the one approving. The necessity of validation emanating from the yearning for love from Odysseus often made Penelope fear love's reciprocation.

Penelope is a protagonist and the heroine. Despite the power relations that exist with her husband, she endures and uses her intelligence that should otherwise give her an equal role and power in Ithaca. As a heroine, she saved herself from Odysseus without help from a man.

Penelope's character depicts the double standard of power relations by showing the powerful's and the powerless's relationships. ${ }^{4}$ Penelope copes with some impunity. However, the choirs of the maids depict Penelope's guilt. The maids' chorus that sends messages of double power standards. The maids say that they were children at one time. Their parents were slaves, wrong and powerless. The maids continue to indicate that their parents were not demigods. The maids' message becomes painful when they continue to explain that they were destined to work and be slaves in the palace. They worked hard from morning to night. When the maids wept, there was nobody to wipe their tears. Whenever they slept, they were woken up. The masters of the maids reminded them that they were motherless, lazy, and dirty. Whenever any son of an honourable man wanted to have sex with the maids, they had no audacity to refuse. ${ }^{5}$

In The Penelopiad, Atwood illustrates double power standards from the victim's and victimizer's roles. The victims complained of torture, abuse, and murder. On the other hand, the victimizers enjoy their power. Therefore, it is evident that a double standard of power relations functions to disadvantage women while benefiting men and society. No man head the cry of the victims at the hand of victimizers. The victims cried that they were roped, strung up, and left dangling. According to the victims, their victimizers must have felt virtuous,

\footnotetext{
${ }^{3}$ Burrow, Ar'Meishia. "A Heroine in Her Own Right: A Character Analysis of Penelope in The Penelopiad." (2017). 4-5

${ }^{4}$ Paiva Henriques, Sara. "Margaret Atwood's The Penelopiad: giving Penelope a voice." Revisitar o Mito| Myths Revisited (2015): 433-443.

${ }^{5}$ Atwood, Margaret. The Penelopiad. New York: Canongate Books Ltd. 2005. 13-14
}

purified, and justified to murder young, innocent girls. Now, the girls are haunting their murderers in the after-life and any forms of life. The girls assure their victimizers that they cannot get rid of them. The innocent girls keep asking why they were murdered without any offence. The girls' victimizers never responded to any question.

According to the girls, their male victimizers felt honourable murdering them. The girls felt powerless because they were only meant to serve at the palace. They were not meant to leave. ${ }^{6}$

The disclosure of power and voice existed with the masculine gender. Even though some feminine characters, such as Penelope, had some say, they had no power. Still, even if a woman has a voice, she may not use it ultimately, as Penelope depicted. Ironically, Penelope has a voice with no power. Furthermore, she has no ultimate audacity to use her voice. Regarding the maids, they voiced their exploitation, but nothing happened. Thus, the double standards of power only worked to benefit men and not women.

\section{Sexual double standards}

Unfaithfulness and adultery among men in The Penelopiad go unpunished. ${ }^{7}$ However, women must refrain from adultery and cheating because it is punishable. A clear picture of the punishment that awaits cheating wives is depicted when Odysseus warns Penelope that she could be "hanged" if she commits adultery. Contrastingly, Odysseus freely commits adultery with Helen. Penelope explains that they "anointed" and "bathed" and bathed each other. ${ }^{8}$ Ironically, the court pronounced no punishment for Odysseus.

Ancient Greece is depicted as a society that placed double sexual standards for women to control them. The premise of women remaining faithful to their husbands gives room for men to commit adultery. The consequences of any woman found committing adultery are severe. Women are subserviently subjected to male dominance.

According to Atwood, men are above honour and can betray their spouses in marriage without facing the consequences. Although there is female advocacy, men feel they are justified to commit adultery. ${ }^{9}$

\footnotetext{
${ }^{6}$ Atwood, Margaret. The Penelopiad. New York: Canongate Books Ltd. 2005. 191-93

${ }^{7}$ Zarra Aldrich, Anna. "Iron Manicures: Sex, Power, and Sedition in Margaret Atwood's Writing." (2020). 28-31

${ }^{9}$ Obidič, Andrejka. "Margaret Atwood's Postcolonial and Postmodern Feminist Novels with Psychological and Mythic Influences: The Archetypal Analysis of the Novel Surfacing." Acta Neophilologica 50, no. 1-2 (2017): 5-24.
} 
Rape is another act of sexual double standards portrayed in the novel. Consenting to the sexual advances of suitors was a survival tactic for the maids. Investigating who raped the maids was a difficult and impossible task. Moreover, people could do nothing if the culprits were men. Penelope pointed out that the maids were raped without their consent. Further analysis of the rape showed it might have involved Odysseus's permission. Men disrespected the bodies of the maids and normalized their handling.

The maids, nonetheless, are not destitute fatalities: they attempt to pursue justice. Chapter 36, "The Chorus Line: The Trial of Odysseus, as Videotaped by the Maids," is exclusively committed to the pursuit of the maids' justice. The abused maids send Odysseus to trial. However, the crime under judgment is not about the rape, but that they committed it without Odysseus's permission. The unnamed maids, executed and repudiated their freedom of speech, are all dominant and revengeful in the underworld. The maids question and protest against the double, unfair sexual standards. These double sexual standards allow Odysseus to commit adultery without punishment, while the maids' sexual relations warrant severe penalties. The maids state that the men at the palace had every woman they could want or choose. The maids note that the palace men had the spear and word at their command.

Atwood criticizes the injustice of murdering the maids via the maids' voices. From the voice of the maids, we realize the brutality and discrimination of Homer's male supermen.

Based on the collective voice of maids, we can recognize their suffering. The maids wonder how men could treat them so inhuman at their young age and dispose of them. The palace men had the power to sell, drown, trade, or use any girl at will. The girls belonged to men. Men had the power to do anything they wanted with them. ${ }^{10}$

Sexual craving and ability have traditionally been perceived as masculine-based. In The Penelopiad, the traditional scene is purported to be a marital rape on the wedding night. "All of this was play-acting. The fiction was that the bride had been stolen. The consummation of a marriage was supposed to be a sanctioned rape. It was supposed to be a conquest, a trampling of a foe, a mock killing. There was supposed to be blood" (44). This statement underpins the premise that women are not entitled to wanting or enjoying sex as their male counterparts.

\footnotetext{
${ }^{10}$ Atwood, Margaret. The Penelopiad. New York: Canongate
} Books Ltd. 2005. 67-8

\section{Double loyalty}

Double loyalty is depicted from infidelity and the constancy of the female gender. Eventually, some women display forced loyalty to their social status. In the novel, light is shed on hegemonic masculinity that can be quite oppressing for women. In the male-dominated ancient Greece society, hypocrisy is prevalent in the prospects of women's loyalty and submissiveness. Women are anticipated to be compliant and faithful to their husbands. Ironically, men are not obligated to be faithful to their wives. Despite women's loyalty, men are justified to become disloyal or unfaithful. Moreover, the concept of compulsory loyalty is explored. For instance, some women have no choice except to be loyal. The twelve maids are examples of forced dedication and compliance to man's dominance.

It is worth noting that double loyalty in the novel also came from other women. For instance, the maids are loyal and obedient to Penelope, who commands them to state insolent statements. Penelope's instruction to the maids becomes a crime for which the maids are hanged. Thus, their demises compensate for their loyalty and compliance. In The Penelopiad, the maids' obligation manifests itself as Odysseus' Attorney asserts that they were justified to be hanged for having unpermitted sex. ${ }^{11}$ Thus, the maids were killed for their purported betrayal of Odysseus, notwithstanding the sexual cruelty that they suffered. The sexual abuse highlights the maids' awful dilemma where they strive to prove their loyalties while lacking free will and decision making.

\section{Double standards of justice}

Justice never prevailed for women in the novel The Panelopiad. ${ }^{12}$ Despite some inequalities in some women, such as Penelope and the maids, they were all oppressed, exploited, and desired. These women did not get the justice they deserved. The maids directly questioned double standards of justice that were skewed against them. The relationship of the maids with the suitors should have raised their status and seek for justice. Ironically, they never got any justice nor social status. With no real love, zero sexual rights, the maids were abused by men. The pain of their hanging reflects double standards of justice in a society that is designed to disadvantage women. The skewed double standards of justice were designed and implemented by the patriarchy of Ithaca. In the Panelopiad, women are seen from the points of blasphemy and murder without justice. These women unite to search for justice.

\footnotetext{
11 ibid

12 Wagoner, Timothy. "“We demand justice!” Directing Margaret Atwood's The Penelopiad in a\# MeToo World." (2020).
} 
Without eyewitnesses and proof of abuse, Telemachus (son of Odysseus) ironically "labelled them as "corrupt". Then, they were murdered brutally. No single individual defended them. The murder of these girls was unquestionable. These girls were named as witches then killed mercilessly.

The maids' justice case is terminated as the story ends. However, they do not give up on claiming their innocence. When the judges summoned Penelope to the court of justice, she likened the maids to her daughters. She described their killing as a "dreadful act of the palace". Furthermore, Penelope maintains that the charge against them was illogical. Ironically, the Judge, sadistically, continues giggling at their case. The Judge's attitude towards the maids' case illustrates how patriarchy reserved its double standards of justice for centuries. The Judge dismissed the case by evaluating the rape as an "unfortunate but insignificant incident" to be exempted to a man with an exceptionally outstanding career.

\section{Traditional narrative double standards}

The 'spear' of Odysseus that the maids refer to appeals to a weaponry image used in the execution, but it is also a phallic symbol that suggests that Odysseus's condemnation power is patriarchal, male power derived from Greek traditions. Additionally, the maids' reference to Odysseus' word' indicates control over language. Odysseus' authority over language demonstrates his ability to manipulate discourse. Through discourse manipulation, Odysseus has ultimate power. By expressing the "word" in their chorus, the maids expose gender double standards imposed on them by Greek traditional narratives. ${ }^{13}$

The maids' last input concerning uncovering gender-based double standards is found in the " $A n$ Anthropology Letter". In the "An Anthropology Letter," the maids observe an unconventional account of their murder. The maids argue that the digit twelve (12) is essential concerning the Greek year's months and their association with the lunar cycle.

Thus, they recommend that they are the "twelve moonmaidens, companions of Artemis, virginal but deadly goddess of the moon". ${ }^{14}$

The maids continue to note that their murder instituted a customary sacrifice. Conversely, the accurate lunar months are thirteen in number. Therefore, the thirteenth cult member is epitomized by Queen Penelope, their mistress. In the sacrificial plan, the bow used to

\footnotetext{
${ }^{13}$ Atwood, Margaret. The Penelopiad. New York: Canongate Books Ltd. 2005. 5-6

${ }^{14}$ Atwood, Margaret. The Penelopiad. New York: Canongate Books Ltd. 2005. 164-165
}

demonstrate Odysseus's identity. Accordingly, Artemis(goddess) is recognized for her weapon preference. Furthermore, the suitors were obligated to use Artemis' bow when shooting via the twelve axe heads. Hence, this chorus proposes that rape and successive hanging of the maids signify a cult. The cult (moon-cult) depicted a rebellion by an inbound group of seizing male-controlled god that worshipped barbarians. The topmost of them, outstandingly Odysseus, would be entitled to kingship by wedding Penelope. The maids would successively be sacrificed. Atwood provides other examples supporting this theory, contributing a dominant feminist annexation of these actions.

\section{Double oppression}

Double oppression points to the maids' social oppression from a slavery perspective and their gender oppression from their patriarchal environment and society. ${ }^{15}$

Men inflicted double oppression on the maids. The author affirms that the hanged maids constantly tormented her. The maids' social and gender oppression points to the widespread abuse of women's social roles and gender roles. Whereas society acknowledges that oppression exists, it is only understood from one standpoint of view. However, for women, we can view it from double standards.

\section{Double roles}

Penelope is viewed from a double role perspective. ${ }^{16}$ She is Odysseus's object and a subject of her own. Penelope runs the palace of Odysseus alone without help. Thus, Odysseus deals with a bright, emphatic Penelope, whose traits and patience matches his own. Penelope also gives the second narration of her current being as an underworld ghost. The twelve murdered maids continuously perturb Odysseus' ghost by singing like owls regarding their murder and failed justice. ${ }^{17}$

\section{CONCLUSION}

Although Atwood's "The Penelopaid" may not be regarded as a feminist dystopia, it sheds light on the feministic perspective. Atwood presents the sufferings of women by pinpointing men and society. Despite the differences in nature, role, and social status of women in

\footnotetext{
${ }^{15}$ Irshad, Shaista, and Niroj Banerji. "Deconstructing Gender and Myth in Margaret Atwood's The Penelopiad." ANGLISTICUM. Journal of the Association-Institute for English Language and American Studies 2, no. 3 (2016): 35-41.

${ }^{16}$ Crews, Avery. "Gender Roles and Societal Breakdowns in Margaret Atwood's The Penelopiad." AKФ (2019): 40-50 17 ibid
} 
The Penelopaid, they all suffer from double standards. Women in The Penelopaid suffered from power inequalities, injustices, sexual abuse, skewed traditional narrative favouring men, forced loyalty, double roles, and double oppression.

The female characters operate in gender-dictated roles and obligations without free will. Justice does not prevail for women even when they cry and plead for it. The novel pinpoints a manipulated $21^{\text {st }}$ court case challenging Odysseus's involvement in the murder of the maids. The maids do not get their justice. The alleged involvement of Odysseus is an illustration that male dominance continues to exist even nowadays. Perhaps one of the factors backing masculine authority is the traditional narrative that is even present in Greek traditions. Atwood elucidates that women may be viewed as essential people from the outside point of view. However, traditionally and from a male perspective, they are suffering from double standards.

\section{REFERENCES}

[1] Atwood, Margaret. "The Penelopiad". New York: Canongate Books Ltd. (2005). 5-193.

[2] Burrow, Ar'Meishia. "A Heroine in Her Own Right: A Character Analysis of Penelope in The Penelopiad." (2017). 1-7

[3] Crews, Avery. "Gender Roles and Societal Breakdowns in Margaret Atwood's The Penelopiad." AKФ (2019): 48-50.

[4] Irshad, Shaista, and Niroj Banerji. "Deconstructing Gender and Myth in Margaret Atwood's The Penelopiad." ANGLISTICUM. Journal of the Association-Institute for English Language and American Studies 2, no. 3 (2016): 35-41.

[5] Obidič, Andrejka. "Margaret Atwood's Postcolonial and Postmodern Feminist Novels with Psychological and Mythic Influences: The Archetypal Analysis of the Novel Surfacing." Acta Neophilologica 50, no. 1-2 (2017): 5-24.

[6] Paiva Henriques, Sara. "Margaret Atwood's The Penelopiad: giving Penelope a voice." Revisitar o Mitol Myths Revisited (2015): 433-443.

[7] Wagoner, Timothy. "“We demand justice!" Directing Margaret Atwood's The Penelopiad in a\# MeToo World." (2020).

[8] Zarra Aldrich, Anna. "Iron Manicures: Sex, Power, and Sedition in Margaret Atwood's Writing." (2020). 28-31. 